\title{
Kinerja Keuangan dan Efisiensi Operasional Perusahaan Proper Peringkat Lebih dari Taat dalam Pengelolaan Lingkungan Hidup
}

\author{
Nyoman Gita Saraswati Ratmayanti ${ }^{1}$ \\ Fakultas Ekonomi dan Bisnis \\ Universitas Udayana, Indonesia
}

\author{
I Gst Ngurah Agung Suaryana² \\ Fakultas Ekonomi dan Bisnis \\ Universitas Udayana, Indonesia
}

Surel : gitasaraswatir@gmail.comm

\section{ABSTRAK}

Obyek penelitian ini adalah kinerja keuangan dan efisiensi operasional perusahaan PROPER dengan data satu tahun sebelum dan sesudah meraih peringkat lebih dari taat atau meraih peringkat hijau atau emas. Teknik analisis yang digunakan adalah uji t-Paired untuk mengetahui perbedaan ratarata kinerja keuangan, dan efisiensi operasional sebelum dan sesudah meraih peringkat Proper hijau. Hasil penelitan menunjukkan bahwa perusahaan-perusahaan yang meraih peringkat Proper hijau, yang memiliki komitmen tinggi dengan taat dan peduli terhadap pengelolaan lingkungan hidup, tidak terdapat perbedaan terhadap peningkatan kinerja keuangan yang dilihat dari ROS, ROA dan ROE. Perusahaan Proper hijau belum mampu meningkatkan efiensi operasionalnya melalui Net Income Efficiency (NIEFF) yaitu kontribusi per pekerja terhadap laba perusahaan. Sales Efficiency (SALEFF) menunjukkan hasil tidak signifikan.

Kata Kunci: Kinerja Keuangan; Efisiensi Oprasional.

\section{Financial Performance and Operational Efficiency of Proper Company Rating More Than Compliant in Environmental Management}

\footnotetext{
ABSTRACT

The object of this study is the financial performance and operational efficiency of the PROPER company with data one year before and after achieving a rating that is more than obedient or achieving a green or gold rating. The analysis technique used was the T-Paired test to determine differences in average financial performance, and operational efficiency before and after achieving the Green Proper rank. The results of the research show that companies that have received the Green Proper rank, which have a high commitment to obedience and care for environmental management, there is no difference in the improvement of financial performance seen from ROS, ROA and ROE. The Green Proper company has not been able to improve its operational efficiency through the Net Income Efficiency (NIEFF), which is the contribution per worker to the company's profit. The Sales Efficiency (SALEFF) shows insignificant results.
}

Keywords: $\quad$ Financial Performance; Operational Efficiency.

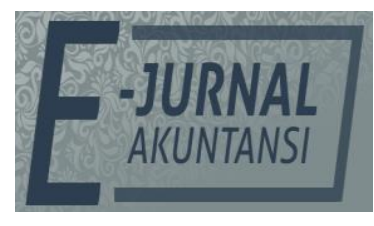

e-ISSN 2302-8556

Vol. 31 No. 1

Denpasar, Januari 2021

Hal. 47-62

DOI:

10.24843/EJA.2021.v31.i01.p04

PENGUTIPAN:

Ratmayanti, N.G.S., \&

Suaryana, I G.N.A. (2021).

Kinerja Keuangan dan

Efisiensi Operasional Perusahaan Proper Peringkat Lebih dari Taat dalam

Pengelolaan Lingkungan Hidup. E-Jurnal Akuntansi, 31(1), 47-62

RIWAYAT ARTIKEL: Artikel Masuk: 31 Oktober 2018 Artikel Diterima: 20 Januari 2021

Artikel dapat diakses : https://ojs.unud.ac.id/index.php/Akuntansi/index 


\section{PENDAHULUAN}

Aktivitas bisnis sering kali dituding sebagai penyebab utama kerusakan lingkungan hidup. Tudingan ini cukup beralasan karena demi memperoleh keuntungan, banyak aktivitas bisnis mencemari, merusak, dan memanfaatkan sumber daya alam tanpa rasa tanggungjawab. Meningkatnya kesadaran masyarakat terhadap pentingnya lingkungan yang lestari bagi semua mahluk hidup, telah ikut mempercepat pergeseran paradigma pengelolaan perusahaan dari stockholder paradigm ke stakeholder paradigm. Besarnya perhatian para pengambil kebijakan terhadap kesejahteraan masyarakat serta pemeliharaan lingkungan hidup telah membuat tujuan pengelolaan perusahaan tidak lagi memberikan penekanan pada kinerja keuangan semata namun juga memberikan penekanan terhadap kinerja sosial dan kinerja lingkungannya. Setiap Perusahan dapat hidup dan berkembang baik jika kinerjannya optimal dan sesuai dengan perubahan lingkungannya, maka dalam menghasilkan laba perusahaan bertanggung jawab terhadap lingkunganya. Kondisi lingkungan yang selalu dipengaruhi dan mempengaruhi perusahaan, dapat menentukan keunggulan alam persaingan. Pendapatan laba kan banyak diperoleh jika perusahaan memperhatikan dan mengelola lingkungan secara intensif (Djogo, 2006).

Tanggung jawab sosial berpengaruh pada kinerja perusahaan. Sebuah pandangan muncul bahwa tanggung jawab sosial atau Corporate Social Responsibility (CSR) perusahaan dapat berpengaruh terhadap kinerja finansial sebuah perusahaan. Pendekatan 'enlightened shareholder approach' menyatakan bahwa pembuatan keputusan perusahaan harus mempertimbangkan berbagai hal mengenai sosial dan lingkungan jika mereka menginginkan keuntungan jangka panjang (Permatasiwi, 2010). Perusahaan yang baik seharusnya membuka informasi seluas-luasnya tentang kuantitas dan kualitas pengelolan lingkungannya, agar keterbukaan informasi yang lengkap perlu selalu dipertahankan, karena hal tersebut merupakan laporan pertanggungjawaban perusahan kepada lingkungan sosial masyarakat.

Aktivitas CSR yang tertuang dalam pengungkapan sosial perusahaan berpengaruh dan memiliki hubungan positif dengan kinerja perusahaan dalam berbagai persepektif yang berbeda penelitian Pfleiger et al., (2005) menunjukan bahwa usaha-usaha pelestarian lingkungan oleh perusahaan akan mendatangkan sejumlah keuntungan, diantaranya ketertarikan pemegang saham dan stakeholder untuk berinvestasi pad perusahaan tertentu akibat pengelolaah lingkungannya yang bertanggung jawab (Suratno et al., 2006) berhasil menemukan bahwa kinerja lingkungan yang baik terbukti penelitian (Rakhiemah \& Agustia, 2009) menemukan bahwa kinerja lingkungan yang dilakukan perusahaan tidak meningkatkan kinerja finansialnnya, namun untuk variabel kinerja lingkungan dan CSR disclousure dapat berfungsi sebagai variabel intervening antara kinerja lingkungan dan kinerja finansial, sesuai dengan penelitian (Sudaryanto, 2011).

Pada penelitian ini mengunakan Legitimacy Theory. Teori legitimasi menyatakan bahwa adanya hubungan kontrak sosial antara perusahaan dengan masyarakat. Kontrak sosial ini berarti perusahaan tidak hanya memajukan perusahaan tetapi harus bertanggung jawab kepada masyarakat, salah satunya dari segi lingkungan di sekitar perusahaan. (Rawi, 2010) menyatakan bahwa 
perusahaan akan selalu berusaha untuk mengoperasikan perusahaan sesuai dengan norma dan aturan yang telah disepakati dengan masyarakat sekitar. Perusahaan yang taat terhadap lingkungan sehingga kinerja lingkungan meningkat menimbulkan kinerja dari segi keuangan perusahaan juga meningkat. Hal ini disebabkan bahwa ketika perusahaan mampu menjaga lingkungan secara otomatis stakeholder akan membeli produknya, sehingga penjualan meningkat dan kinerja keuangan menjadi meningkat. Setyaningsih \& Asyik, (2016) menjelaskan bahwa kinerja keuangan meningkat disebabkan oleh kinerja lingkungan yang baik.

Mengenai kewajiban setiap orang di Indonesia untuk memelihara kelestarian fungsi lingkungan hidup serta mencegah dan menanggulangi pencemaran dan perusakan lingkungan hidup diatur dalam Undang-undang RI Nomor 23 Tahun 1997 tentang Pengelolaan Lingkungan Hidup. Sebelumnya, sejak tahun 1995 pemerintah melalui Kementrian Lingkungan Hidup (KLH) telah pula menerapkan program penataan lingkungan dalam upaya mencegah kerusakan lingkungan yang dikenal dengan Program Penilaian Peringkat Kinerja Perusahaan dalam Pengelolaan Lingkungan Hidup (disingkat PROPER).

Pada awalnya, pelaksanaan PROPER difokuskan pada penilaian peringkat kinerja penaatan perusahaan terhadap pengendalian pencemaran air dari perusahaan yang masuk dalam Program Kali Bersih (disingkat PROKASIH) sebagai penaatan untuk media tunggal yaitu pengendalian pencemaran air saja. Guna memberikan gambaran kinerja penaatan perusahaan lebih menyeluruh, maka sejak tahun 2002 aspek penilaian kinerja penaatan diperluas dari media tunggal menjadi multimedia dengan penilaian mencakup: penaatan terhadap pengendalian pencemaran air, udara, pengelolaan limbah Bahan Berbahaya dan Beracun yang di singkat dengan B3, dan penerapan AMDAL (Analisis Mengenai Dampak Lingkungan).

Sampai saat ini PROPER dengan aspek multimedia telah dilaksanakan selama 16 tahun, yaitu sejak tahun 2002 hingga 2018. Pentingnya kelestarian lingkungan hidup untuk masa sekarang hingga masa yang akan datang, secara eksplisit menunjukkan bahwa perjuangan manusia untuk menyelamatkan lingkungan hidup harus dilakukan secara berkesinambungan, dengan jaminan estafet antargenerasi yang dapat dipertanggungjawabkan.Semakin besar jumlah perusahaan PROPER maka dampak peningkatan kinerja penaatan perusahaan PROPER terhadap peningkatan kualitas lingkungan akan signifikan. Pada saat ini jumlah perusahaan PROPER memang masih rendah dibandingkan dengan dengan total jumlah perusahaan yang berpotensi untuk dilakukan penilaian peringkatnya, yaitu 8.000 - 10.000 perusahaan. Pada periode penilaian PROPER 2016 - 2017 jumlah perusahaan PROPER mencapai 1819 perusahaan. Jumlah ini menurun dari tahun sebelumnya yaitu 1930 perusahaan. Pada tahun mendatang diharapkan perusahaan PROPER dapat meningkat lebih signifikan. Tingkat kepatuhan perusahaan pada Program Penilaian Peringkat Kinerja (Proper) Pengelolaan Lingkungan oleh perusahaan tahun ini mencapai angka 92\%. Angka tersebut naik 7\% bila dibandingkan dengan 2016 dengan tingkat kepatuhan 85\%. Peningkatan kepatuhan Proper itu merupakan satu gambaran semakin sadarnya perusahaan dalam pelaksanaan sistem kerja yang berkelanjutan. "Dapat dilihat, tingkat kepatuhan terus meningkat. Hasilnya peningkatannya oleh perusahaan 
luar biasa," nilai rata-rata respons perusahaan pada Proper tahun ini juga kembali meningkat. Bila pada 2015 nilai rata-rata respons perusahaan pada semua poin penilaian Proper hanya 27\%, tahun ini mencapai 31\%. Berdasarkan data KLHK, tahun ini yang mendapatkan penilaian Proper ialah 1.819 perusahaan. Dari jumlah tersebut, terdapat 19 peraih Proper emas. Angka itu juga meningkat jika dibandingkan dengan tahun lalu sebanyak 12 Proper emas. Karliansyah mengungkapkan, jumlah perusahaan berstatus merah atau melakukan pelanggaran dan melanggar sebagian syarat pada tahun ini juga menurun, menjadi 131 perusahaan jika dibandingkan dengan 2016, sebanyak 284 perusahaan. (Media Indonesia, 2018)

Sejauh ini PROPER merupakan satu-satunya kegiatan pemeringkatan yang menggunakan lima peringkat warna. Dalam aspek komunikasi, penggunaan peringkat warna akan lebih mudah dipahami dan diingat oleh masyarakat. Penggunaan peringkat warna juga memberikan efek insentif dan disinfentif reputasi bagi masing-masing perusahaan. Lima peringkat warna yang digunakan mencakup peringkat Hitam, Merah, Biru, Hijau, dan Emas. Peringkat Emas dan Hijau untuk perusahaan yang telah melakukan upaya lebih dari taat dan patut menjadi contoh. Peringkat Biru bagi perusahaan yang telah taat, dan peringkat Merah dan Hitam bagi perusahaan yang belum taat. Pada Tabel 1, dapat dilihat hasil penilaian peringkat pada periode 2016 dan 2017.

Sebagai instrumen penaatan alternatif, PROPER telah dipuji oleh berbagai pihak termasuk Bank Dunia, bahkan PROPER menjadi salah satu bahan studi kasus di Harvard Institute for International Development (HIID). Sejak dikembangkan di Indonesia mulai tahun 1995, PROPER telah menjadi contoh di berbagai negara di Asia, Amerika Latin dan Afrika sebagai instrumen penaatan alternatif. Pada tahun 1996, PROPER mendapatkan penghargaan Zero Emission Award dari United Nations University di Tokyo.

Berbagai penelitian dengan menggunakan cara dan metoda yang berbedabeda telah dilakukan untuk membuktikan secara empiris hubungan antara kinerja lingkungan dengan kinerja keuangan perusahaan. Benny Dwi Saputra Kamsum, (2007) menemukan bahwa kinerja lingkungan dan pengungkapan informasi lingkungan secara bersama-sama atau simultan memiliki kemampuan mempengaruhi kinerja ekonomi perusahaan manufaktur yang terdaftar di Bursa Efek Indonesia pada tingkat kepercayaan 95\%. Nugraha, (2007) menguji pengaruh kinerja lingkungan perusahaan terhadap kinerja keuangan. Kinerja lingkungan diukur dengan peringkat PROPER, sedangkan kinerja keuangan didefinisikan sebagai profitabilitas dan diukur dengan tingkat pengembalian aset. Hasil penelitiannya memberikan kesimpulan bahwa semakin baik kinerja lingkungan perusahaan akan semakin baik pula kinerja keuangannya. Sementara itu penelitian Almilia \& Wijayanto, (2007) menunjukkan hasil bahwa variabel Environmental Performance, Unexpected Earning, Pre-Disclosure Environment, Growth Opportunities, dan Profit Margin secara bersama-sama tidak memiliki pengaruh yang signifikan terhadap variabel Economic Performance.

Penelitian-penelitian tersebut nampaknya menunjukkan hasil yang tidak konsisten yang kemungkinan disebabkan oleh: (1) program penataan lingkungan relatif baru di terapkan Indonesia, sehingga kinerja lingkungan belum menjadi 
perhatian investor dalam pengambilan keputusan investasi; dan (2) jumlah sampel penelitian relatif sedikit dengan peringkat kinerja bervariasi (heterogen).

Berdasarkan latar belakang yang telah diuraikan, masih sangat menarik dilakukan pengujian tentang masalah-masalah yang terkait dengan kinerja keuangan dan kinerja penataan lingkungan. Pada penelitian ini akan dianalisis kinerja keuangan yang meliputi profitabilitas, dan kinerja operasional sebelum dan sesudah perusahaan PROPER meraih kategori lebih dari taat dan patut menjadi contoh (peringkat emas dan hijau) dalam upaya penataan lingkungan. Bagi perusahaan yang belum menjadi target peserta PROPER dan tidak memenuhi kriteria tersebut, pengawasan dilakukan melalui instrumen pengawasan sebagaimana biasanya.

Pelaksanaan program ini dilakukan secara terintegrasi dengan melibatkan berbagai stakeholder. Mulai dari tahapan penyusunan kriteria penilaian PROPER, pemilihan perusahaan, penentuan peringkat, sampai pada pengumuman peringkat kinerja kepada publik. Untuk memudahkan masyarakat dan para stakeholder memahami tingkat kinerja penaatan masing-masing perusahaan dan guna membuka lebih besar lagi ruang apresiasi bagi perusahaan yang telah meningkatkan kinerja penaatannya, maka saat ini kinerja perusahaan dikategorikan lima peringkat warna dengan tujuh kategori.

Sejauh ini PROPER merupakan satu-satunya kegiatan pemeringkatan yang menggunakan lima peringkat warna. Pada umumnya peringkat menggunakan huruf, angka dan bintang. Dalam aspek komunikasi, penggunaan peringkat warna akan lebih mudah dipahami dan diingat oleh masyarakat. Penggunaan peringkat warna juga memberikan efek insentif dan disinfentif reputasi bagi masing-masing perusahaan.

\section{Tabel 1. Peringkat Warna Proper}

\begin{tabular}{llllcc}
\hline Tingkat Penaatan & \multicolumn{3}{c}{ Alternatif Peringkat } & \multicolumn{2}{c}{ Efek publikasi yang diharapkan } \\
\hline \multirow{2}{*}{ Lebih dari taat } & $\mathrm{A}$ & $* * * *$ & Emas & Insentif Reputasi & Penghargaan \\
\multirow{2}{*}{ Taat } & $\mathrm{B}$ & $* * * *$ & Hijau & & \\
\multirow{2}{*}{ Belum taat } & $\mathrm{C}$ & $* * *$ & Biru & & \\
& $\mathrm{D}$ & $* *$ & Merah & Disinsentif & Tekanan \\
& $\mathrm{E}$ & $*$ & Hitam & Reputasi & Stakeholder \\
\hline
\end{tabular}

Sumber: Sekretariat PROPER, Kementrian Lingkungan Hidup RI, 2018

Lima peringkat warna yang digunakan mencakup peringkat Hitam, Merah, Biru, Hijau, dan Emas. Peringkat Emas dan Hijau untuk perusahaan yang telah melakukan upaya lebih dari taat dan patut menjadi contoh. Peringkat Biru bagi perusahaan yang telah taat, dan peringkat Merah dan Hitam bagi perusahaan yang belum taat.

Benny \& Azhar (2007) menemukan bahwa kinerja lingkungan dan pengungkapan informasi lingkungan secara bersama-sama atau simultan memiliki kemampuan mempengaruhi kinerja ekonomi perusahaan manufaktur yang terdaftar di Bursa Efek Indonesia pada tingkat kepercayaan 95\%.

Nugraha (2007) menguji pengaruh kinerja lingkungan perusahaan terhadap kinerja keuangan. Kinerja lingkungan diukur dengan peringkat PROPER sedangkan kinerja keuangan didefinisikan sebagai profitabilitas dan diukur dengan tingkat pengembalian aset. Hasil penelitiannya memberikan 
kesimpulan bahwa semakin baik kinerja lingkungan perusahaan akan semakin baik pula kinerja keuangannya.

\section{Tabel 2. Penjelasan Indikator Warna PROPER}

\begin{tabular}{ll}
\hline Indikator Warna & \multicolumn{1}{c}{ Penjelasan Warna } \\
\hline Emas & $\begin{array}{l}\text { Telah melakukan pengelolaan lingkungan lebih dari yang } \\
\text { dipersyaratkan dan telah melakukan upaya 3R (Reduce, Reuse, } \\
\text { Recycle) menerapkan sistem pengelolaan lingkungan yang } \\
\text { berkesinambungan, serta melakukan upaya-upaya yang berguna } \\
\text { bagi kepentingan masyarakat pada jangka panjang } \\
\text { Telah melakukan pengelolaan lingkungan lebih dari yang } \\
\text { dipersyaratkan, telah mempunyai sistem pengelolaan lingkungan, } \\
\text { mempunyai hubungan yang baik dengan masyarakat, termasuk } \\
\text { melakukan upaya 3R (Reduce, Reuse, Recycle) }\end{array}$ \\
Hijau & $\begin{array}{l}\text { Telah melakukan upaya pengelolaan lingkungan yang } \\
\text { dipersyaratkan sesuai dengan ketentuan atau peraturan yang } \\
\text { berlaku }\end{array}$ \\
Biru & $\begin{array}{l}\text { Melakukan upaya pengelolaan lingkungan, akan tetapi beberapa } \\
\text { upaya belum mencapai hasil yang sesuai dengan persyaratan } \\
\text { sebagaimana diatur dalam peraturan perundang-undangan }\end{array}$ \\
Minus & $\begin{array}{l}\text { Melakukan upaya pengelolaan lingkungan, akan tetapi baru } \\
\text { sebagian mencapai hasil yang sesuai dengan persyaratan } \\
\text { sebagaimana diatur dalam peraturan perundang-undangan }\end{array}$ \\
Merah & $\begin{array}{l}\text { Melakukan upaya pengelolaan lingkungan, akan tetapi baru } \\
\text { sebagian kecil mencapai hasil yang sesuai dengan persyaratan } \\
\text { sebagaimana diatur dalam peraturan perundang-undangan } \\
\text { Belum melakukan upaya pengelolaan lingkungan berarti, secara } \\
\text { sengaja tidak melakukan upaya pengelolaan lingkungan } \\
\text { sebagaimana yang dipersyaratkan, serta berpotensi mencemari } \\
\text { lingkungan }\end{array}$ \\
Merah Minus &
\end{tabular}

Sumber: Sekretariat PROPER, Kementrian Lingkungan Hidup RI, 2018

Luciana \& Dwi (2007) menunjukkan hasil bahwa variabel Environmental Performance, Unexpected Earning, Pre-Disclosure Environment, Growth Opportunities, dan Profit Margin secara bersama-sama tidak memiliki pengaruh yang signifikan terhadap variabel Economic Performance.

Al-Tuwaijri, et al., (2003) dalam penelitiannya yang berjudul "The Relations Among Environmental Disclosure, Environmental Performance, and Economic Performance : A Simultaneous Equation Approach", bahwa terdapat hubungan antara kinerja lingkungan yang baik dengan kinerja ekonomi yang baik pula. Kemudian pengungkapan lingkungan pada masa sekarang dan pada masa yang akan datang, seharusnya sesuai dengan CSR dan profitabilitas ekonomi perusahaan. Al-Tuwaijri menggunakan persamaan simultan dengan pengukuran regresi 3SLS (Three Stage Least Square) untuk mengetahui hubungan antara pengungkapan lingkungan, kinerja lingkungan dan kinerja ekonomi. 
Sarumpaet (2005) menyatakan bahwa "The relationship between environmental performance and financial performance of Indonesian company" menguji hubungan antara kinerja lingkungan dan kinerja keuangan perusahaanperusahaan di Indonesia. Kinerja lingkungan yang diteliti diukur dengan mengunakan rating kinerja lingkungan perusahaan atau PROPER yang disediakan oleh Bapedal atau Kementerian Lingkungan Hidup RI, sedangkan kinerja keuangan diukur dengan ROA (Return On Assets). Penelitian tersebut membuktikan bahwa tidak ada hubungan yang signifikan antara kinerja lingkungan dan kinerja keuangan perusahaan, akan tetapi ukuran perusahaan, listing di BEJ dan ISO 14001 berhubungan secara signifikan terhadap kinerja lingkungan. Penelitian ini juga membuktikan bahwa rating PROPER, yang disediakan oleh pemerintah Indonesia, cukup terpercaya sebagai ukuran kinerja lingkungan perusahaan, karena kesesuaiannya dengan sertifikasi internasional di bidang lingkungan, ISO 14001.

Suratno, et al., (2006) melalui mengungkapkan bahwa environmental performance berpengaruh secara positif signifikan terhadap environmental disclosure dan juga berpengaruh positif signifikan terhadap economic performance. Nuraini (2010) melakukan penelitian tentang pengaruh environmental performance dan environmental disclosure terhadap economic performance pada perusahaan yang terdaftar di Bursa Efek Indonesia. Hasil penelitian menunjukan bahwa environmental performance tidak berpengaruh secara signifkan terhadap economic performance, environmental dislosure tidak berpengaruh secara signifikan terhadap economic performance, dan dari empat variabel kontrol (profit margin (PM), environmental concerns (EnC), firm size (Sz) dan ownership (Own) yang digunakan, hanya dua variable yang sisignifikan terhadap pengaruh terhadap economic performance yaitu variable profit margin dan ownership. Rakhiemah \& Agustia (2009) juga menguji hal yang sama namun mereka tidak menemukan pengaruh positif signifikan karena kinerja lingkungan bukanlah salah satu factor yang menentukan pengaruh positif signifikan karena kinerja lingkungan bukanlah salah satu faktor yang menentukan fluktasi harga saham.

Penelitian ini bermaksud menguji terjadinya peningkatan kinerja keuangan dan efisiensi operasional pada perusahaan PROPER setelah meraih peringkat lebih dari taat. Kerangka berpikir diawali dengan studi teoritis untuk mengkaji teori-teori yang relevan dengan permasalahan yang akan dipecahkan, yaitu teori Teori Stakeholer dan Teori Legistimasi dan sebagai grand teori terdapat Kinerja Keuangan dan Efisiensi Operasional teori Tanggungjawab Perusahaan Terhadap Lingkungan dan Mekanisme Kinerja Proper sebagai supporting theory. Kajian teori menuntun berpikir deduktif, yaitu suatu proses yang dimulai berpikir secara umum, baru kemudian khusus. Selain melakukan kajian atas teori-teori yang relevan, penelitian ini juga melakukan studi empirik yang bersumber pada penelitian-penelitian terdahulu yang relevan dengan penelitian ini. Studi empirik dilakukan untuk menuntun berpikir induktif, yaitu dari khusus ke umum, sehingga alur berpikir dalam penelitian ini tidak hanya didasarkan atas pemikiran deduktif atau induktif saja, tetapi kombinasi keduanya, karena saling mendukung.

Berdasarkan pendahuluan yang telah dikemukakan hipotesis sebagai berikut: "Diduga bahwa perusahaann perusahaan PROPER mengalami 
peningkatan kinerja keuangan dan efisiensi operasional setelah meraih peringkat lebih dari taat dalam pengelolaan lingkungan hidup".

\section{METODE PENELITIAN}

Penelitian dilakukan pada perusahaan peserta PROPER yang dilaksanakan oleh Kementerian Lingkungan Hidup RI, yang terdaftar di Bursa Efek Indonesia. Obyek penelitian ini adalah kinerja keuangan dan efisiensi operasional perusahaan PROPER dengan data satu tahun sebelum dan sesudah meraih peringkat lebih dari taat atau meraih peringkat hijau atau emas.

Rasio profitabilitas adalah rasio yang mengukur kemampuan perusahaan dalam menghasilkan laba. Rasio profitabilitas terdiri dari: Gross Profit Margin, Net Profit Margin, Return on Assets, Return on Equity, Return on Sales dan Operating Ratio. Penelitian ini menggunakan proksi dengan 3 rasio keuangan, yaitu:

Return on Sales $(\mathrm{ROS})=$ Net Income/Net Sales.

Rasio ini menunjukkan kemampuan perusahaan memperoleh laba dari tingkat penjualannya dengan satuan persen. Seacara umum ROS (perputaran penjualan) menggambarkan atau dilihat sebagai gambaran yang positif karena menunjukkan kemampuan perusahaan untuk memperoleh nilai tertentu. Menurut Munawir, (2005) tingkat perputaran berkaitan dengan penjualan, pendapatan bersih, dan laba per lembar saham. Menurut (Simamora, 2004) penjualan (sales) menggambarkan suatu ukuran dari kenaikan aktiva (biasanya dalam bentuk peningkatan kas dan piutang dagang) disebabkan penjualan produk atau persediaan barang dagangan. Dengan demikian perputaran dapat dilihat dari dua sisi, yaitu dari sisi penjualan (sales) dan aset.

Return on Assets (ROA) = Net Income/Total Assets....

Rasio ini menunjukkan kemampuan perusahaan memperoleh laba dari total assets dengan satuan persen. Menurut (Lesatari \& Sugiharto, 2007 : 196) dalam (Rinati, 2008:6) ROA adalah rasio yang digunakan untuk mengukur keuntungn bersih yang diperoleh dari penggunaan aktiva. Dengan kata lain, semakin tinggi rasio ini maka semakin baik produktivitas assets dalam memperoleh keuntungan bersih. Hal ini selanjutnya akan meningkatkan daya tarik perusahaan kepada investor. Peningkatan daya tarik perusahaan tersebut makin diminati investor, karena tingkat pengembalian akan semakin besar. Hal ini juga akan berdampak bahwa harga saham dari perusahaan tersebut dipasar modal juga akan semakin tinggi sehingga ROA akan berpengaruh terhadap harga saham perusahaan. Menurut Sugiharto, (2007 : 196) dalam Rinati, (2008: 6) angka ROA dapat diketahui baik apabila lebih besar 2\%. Tandelilin, (2010: 372) ROA (Return On Assets) menggambarkan sejauh mana kemampuan aset - aset yang dimiliki perusahaan bisa mengahsilkan laba (Sawir, 2001 : 19), untuk menghitung ROA, ada yang ingin menambahkan bunga setelah pajak dalam pembilang dari rasio tersebut. Teori ini didasarkan pada pendapat bahwa karena aktiva didanai oleh pemengang saham dan kreditor, maka rasio harus dapat memberikan ukuran produktivitas aktiva dalam memberikan pengembalian kepada kedua penanam modal itu.

Return on Equity (ROE) = Net Income/Equity. 
Rasio ini menunjukkan kemampuan perusahaan memperoleh laba dari ekuitasnya dengan satuan persen.Return on equity (ROE) dimaksudkan untuk mengukur kemampuan perusahaan dalam menghasilkan laba bersih berdasarkan modal saham tertentu.

Menurut Munawir, (2001), ROE adalah rasio yang menunjukkan tingkat keuntungan dari investasi yang ditanamkan oleh pemegang saham. Syamsuddin, (1978), ROE merupakan suatu pengukuran dari penghasilan (income) yang tersedia bagi para pemilik perusahaan atau modal yang mereka investasikan pada perusahaan.

ROE digunakan untuk mengukur tingkat kembalian perusahaan atau efektifitas perusahaan dalam menghasilkan keuntungan dengan memanfaatkan ukuran profitabilitas dan sudut pandang pemegang saham (Hanafi \& Halim, 2009). Jika rasio ini meningkat maka manajemen dipandang telah mengelola perusahaan dengan efisien.

Efisiensi operasional menunjukkan besarnya kontribusi pekerja terhadap penjualan dan laba. Variabel ini mempunyai satuan rupiah per pekerja yang diproksi dengan rumus berikut.

Sales Efficiency $(\mathrm{SALEFF})=$ Total Sales/Total Employment

Net Income Efficiency (NIEFF) = Net Income/Total Employment.

Populasi dalam penelitian ini adalah seluruh peserta PROPER Periode 2014, 2015, dan 2016. Dari populasi tersebut, sampel diambil dengan metode purposive sampling, yaitu sampel ditarik sejumlah tertentu dari populasi dengan menggunakan pertimbangan tertentu. Pada tahun 2014, 2015 dan 2016 terdapat populasi sebesar 9 populasi dan sampel yang di dapat sebesar 9 sempel.

Uji T Paired atau Paired T Test digunakan sebagai uji komparatif atau perbedaan apabila skala data kedua variabel adalah kuantitatif (Interval atau Rasio). Uji ini disebut juga dengan istilah pairing $T$ Test. Untuk dapat melihat adanya peningkatan kinerja sebelum dan sesudah meraih peringkat lebih dari taat, diolah satu sebelum dan satu sesudah meraih peringkat lebih dari taat. Sementara itu, tahun pada saat perusahaan tersebut meraih peringkat lebih dari taat dianggap sebagai tahun 0 atau tahun transisi, dimana pada saat tersebut terjadi percampuran antara kinerja sebelum dan sesudah meraih peringkat lebih dari taat.

\section{HASIL DAN PEMBAHASAN}

Berdasarkan hasil analisis deskriptif dengan bantuan SPSS 24.0 For Windows dapat dibuat tabel hasil analisis deskriptif ROS sebelum dan sesudah mendapat penghargaan sebagai berikut.

Tabel 3. Hasil Analisis Deskriptif ROS

\begin{tabular}{lllll}
\hline ROS & Mean & Selisih & Persentase (\%) & Std. Deviation \\
\hline Sebelum & 0,149 & \multirow{2}{*}{0,021} & \multirow{2}{*}{14,13} & 0,089 \\
Sesudah & 0,128 & \multirow{2}{*}{0,085} \\
\hline
\end{tabular}

Sumber: Data Penelitian, 2018

Berdasarkan Tabel 3, dapat dilihat nilai rata - rata ROS sebelum mendapat penghargaan sebesar 0,149 dengan standar deviasi 0,089 sedangkan nilai ratarata ROS sesudah mendapat penghargaan sebesar 0,128 dengan standar deviasi 0,085. Hal ini menunjukkan terjadi penurunan ROS setelah mendapat 
penghargaan sebesar 0,021 dengan persentase penurunan sebesar 14,13\%. Berdasarkan hasil analisis deskriptif dengan bantuan SPSS 24.0 For Windows dapat dibuat tabel hasil analisis deskriptif ROA sebelum dan sesudah mendapat penghargaan sebagai berikut.

Tabel 4. Hasil Analisis Deskriptif ROA

\begin{tabular}{lllll}
\hline ROA & Mean & Selisih & Persentase (\%) & Std. Deviation \\
\hline Sebelum & 0,140 & \multirow{2}{*}{0,013} & \multirow{2}{*}{9,19} & 0,125 \\
Sesudah & 0,127 & \multirow{2}{*}{0,104} \\
\hline
\end{tabular}

Sumber: Data Penelitian, 2018

Berdasarkan Tabel 4, dapat dilihat nilai rata - rata ROA sebelum mendapat penghargaan sebesar 0,140 dengan standar deviasi 0,125 sedangkan nilai rata rata ROA sesudah mendapat penghargaan sebesar 0,127 dengan standar deviasi 0,104 . Hal ini menunjukkan terjadi penurunan ROA setelah mendapat penghargaan sebesar 0,013 dengan persentase penurunan sebesar 9,19\%. Berdasarkan hasil analisis deskriptif dengan bantuan SPSS 24.0 For Windows dapat dibuat tabel hasil analisis deskriptif ROE sebelum dan sesudah mendapat penghargaan sebagai berikut.

Tabel 5. Hasil Analisis Deskriptif ROE

\begin{tabular}{lllll}
\hline ROE & Mean & Selisih & Persentase (\%) & Std. Deviation \\
\hline Sebelum & 0,261 & \multirow{2}{*}{0,194} & \multirow{2}{*}{74,39} & 0,383 \\
Sesudah & 0,456 & & & 0,618 \\
\hline
\end{tabular}

Sumber: Data Penelitian, 2018

Berdasarkan Tabel 5, dapat dilihat nilai rata - rata ROE sebelum mendapat penghargaan sebesar 0,261 dengan standar deviasi 0,383 sedangkan nilai rata - rata ROE sesudah mendapat penghargaan sebesar 0,456 dengan standar deviasi 0,618. Hal ini menunjukkan terjadi peningkatan ROE setelah mendapat penghargaan sebesar 0,194 dengan persentase peningkatan sebesar 74,39\%. Berdasarkan hasil analisis deskriptif dengan bantuan SPSS 24.0 For Windows dapat dibuat tabel hasil analisis deskriptif SALEFF sebelum dan sesudah mendapat penghargaan sebagai berikut.

Tabel 6. Hasil Analisis Deskriptif SALEFF

\begin{tabular}{lllll}
\hline SALEFF & Mean & Selisih & Persentase (\%) & Std. Deviation \\
\hline Sebelum & $934.397,810$ & \multirow{2}{*}{$487.741,67$} & \multirow{2}{*}{52,20} & $1.855651,832$ \\
Sesudah & $446.656,148$ & & $1.072 .123,000$ \\
\hline
\end{tabular}

Sumber: Data Penelitian, 2018

Berdasarkan Tabel 6, dapat dilihat nilai rata - rata SALEFF sebelum mendapat penghargaan sebesar 934.397,810 dengan standar deviasi 1.855.651,832 sedangkan nilai rata-rata SALEFF sesudah mendapat penghargaan sebesar 446.656,148 dengan standar deviasi 1.075.123,000. Hal ini menunjukkan terjadi penurunan SALEFF setelah mendapat penghargaan sebesar 487.741,67 dengan persentase penurunan sebesar $52,20 \%$.

\section{Tabel 7. Hasil Analisis Deskriptif NIEFF}

\begin{tabular}{lllll}
\hline NIEFF & Mean & Selisih & Persentase (\%) & $\begin{array}{l}\text { Std. } \\
\text { Deviation }\end{array}$ \\
\hline $\begin{array}{l}\text { Sebelum } \\
\text { Sesudah }\end{array}$ & $111.371,872$ & $59.737,305$ & 53,64 & $280.364,422$ \\
\hline
\end{tabular}

Sumber: Data Penelitian, 2018 
Berdasarkan Tabel 7, dapat dilihat nilai rata - rata NIEFF sebelum mendapat penghargaan sebesar 111.371,872 dengan standar deviasi 280.364,422 sedangkan nilai rata - rata NIEFF sesudah mendapat penghargaan sebesar 51.634,189 dengan standar deviasi 153.474,272. Hal ini menunjukkan terjadi penurunan NIEFF setelah mendapat penghargaan sebesar 59.737,305 dengan persentase penurunan sebesar 53,64\%. Dalam penelitian ini untuk menguji hipotesis digunakan Paired $T$ Test dimana, uji ini digunakan sebagai uji komparatif atau perbedaan apabila skala data kedua variabel adalah kuantitatif (Interval atau Rasio). Berdasarkan hasil uji SPSS 24.0 for windows diperoleh tabel hasil uji Paired T Test ROS sebagai berikut.

Tabel 8. Hasil Uji Uji Paired t-test Data ROS

\begin{tabular}{lllll}
\hline ROS & t- hitung & t- tabel & signifikansi & Keterangan \\
\hline $\begin{array}{l}\text { Sebelum } \\
\text { Sesudah }\end{array}$ & 1,285 & 2,306 & 0,235 & Tidak \\
\hline
\end{tabular}

Sumber: Data Penelitian, 2018

Berdasarkan Tabel 8, diperoleh nilai $\mathrm{t}$ hitung sebesar 1,285 dan nilai $\mathrm{t}$ tabel yang diperoleh dari tabel $\mathrm{t}$ dengan signifikan 0,05 dan derajat kebebasan $\mathrm{N}-\mathrm{k}=$ $9-1=8$ yakni 2,306 . Karena nilai $t$ hitung $<\mathrm{t}$ tabel $(1,285<2,306)$ dengan nilai signifikan > 0,05 $(0,235>0,05)$, sehingga dapat disimpulkan bahwa $\mathrm{H}_{1}$ ditolak atau dengan kata lain tidak terdapat peningkatan ROS sesudah meraih peringkat lebih dari taat. Berdasarkan hasil uji SPSS 24.0 for windows diperoleh tabel hasil uji Paired T Test ROA sebagai berikut.

Tabel 9. Hasil Uji Uji Paired t-test Data ROA

\begin{tabular}{lllll}
\hline ROA & $\mathrm{t}$ - hitung & $\mathrm{t}$ - tabel & signifikansi & Keterangan \\
\hline $\begin{array}{l}\text { Sebelum } \\
\text { Sesudah }\end{array}$ & 0,914 & 2,306 & 0,387 & Tidak \\
\hline
\end{tabular}

Sumber: Data Penelitian, 2018

Berdasarkan Tabel 9, diperoleh nilai $t$ hitung sebesar 0,914 dan nilai $t$ tabel yang diperoleh dari tabel $\mathrm{t}$ dengan signifikan 0,05 dan derajat kebebasan $\mathrm{N}-\mathrm{k}=$ $9-1=8$ yakni 2,306 . Karena nilai $\mathrm{t}$ hitung $<\mathrm{t}$ tabel $(0,914<2,306)$ dengan nilai signifikan $>0,05(0,387>0,05)$, sehingga dapat disimpulkan bahwa $\mathrm{H}_{1}$ ditolak atau dengan kata lain tidak terdapat peningkatan ROA sesudah meraih peringkat lebih dari taat. Berdasarkan hasil uji SPSS 24.0 for windows diperoleh tabel hasil uji Paired T Test ROE sebagai berikut.

Tabel 10. Hasil Uji Uji Paired t-test Data ROE

\begin{tabular}{lllll}
\hline ROE & $\mathrm{t}$ - hitung & $\mathrm{t}$ - tabel & signifikansi & Keterangan \\
\hline $\begin{array}{l}\text { Sebelum } \\
\text { Sesudah }\end{array}$ & 1,021 & 2,306 & 0,337 & Tidak Signfikan \\
\hline
\end{tabular}

Sumber: Data Penelitian, 2018

Berdasarkan Tabel 10, diperoleh nilai thitung sebesar 1,021 dan nilai $\mathrm{t}$ tabel yang diperoleh dari tabel $\mathrm{t}$ dengan signifikan 0,05 dan derajat kebebasan $\mathrm{N}-\mathrm{k}=$ $9-1=8$ yakni 2,306 . Karena nilai $t$ hitung $<\mathrm{t}$ tabel $(1,021<2,306)$ dengan nilai signifikan > 0,05 $(0,337>0,05)$, sehingga dapat disimpulkan bahwa $\mathrm{H}_{1}$ ditolak atau dengan kata lain tidak terdapat peningkatan ROE sesudah meraih peringkat lebih dari taat. Berdasarkan hasil uji SPSS 24.0 for windows diperoleh tabel hasil uji Paired T Test SALEFF sebagai berikut. 
Tabel 11. Hasil Uji Uji Paired t-test Data SALEFF

\begin{tabular}{lllll}
\hline SALEFF & t- hitung & t- tabel & signifikansi & Keterangan \\
\hline $\begin{array}{l}\text { Sebelum } \\
\text { Sesudah }\end{array}$ & 1,153 & 2,306 & 0,282 & $\begin{array}{l}\text { Tidak } \\
\text { Signfikan }\end{array}$ \\
\hline
\end{tabular}

Sumber: Data Penelitian, 2018

Berdasarkan Tabel 11, diperoleh nilai $t$ hitung sebesar 1,153 dan nilai $t$ tabel yang diperoleh dari tabel $\mathrm{t}$ dengan signifikan 0,05 dan derajat kebebasan $\mathrm{N}-\mathrm{k}=$ $9-1=8$ yakni 2,306 . Karena nilai $\mathrm{t}$ hitung $<\mathrm{t}$ tabel $(1,153<2,306)$ dengan nilai signifikan $>0,05(0,282>0,05)$, sehingga dapat disimpulkan bahwa $\mathrm{H}_{0}$ diterima atau dengan kata lain tidak terdapat peningkatan SALEFF sesudah meraih peringkat lebih dari taat. Berdasarkan hasil uji SPSS 24.0 for windows diperoleh tabel hasil uji Paired T Test NIEFF sebagai berikut.

Tabel 12. Hasil Uji Uji Paired t-test Data NIEFF

\begin{tabular}{lllll}
\hline NIEFF & $\mathrm{t}$ - hitung & $\mathrm{t}$ - tabel & signifikansi & Keterangan \\
\hline $\begin{array}{l}\text { Sebelum } \\
\text { Sesudah }\end{array}$ & 0,560 & 2,306 & 0,591 & Tidak Signfikan
\end{tabular}

Sumber: Data Penelitian, 2018

Berdasarkan Tabel 12, diperoleh nilai thitung sebesar 2,580 dan nilai $t$ tabel yang diperoleh dari tabel $\mathrm{t}$ dengan signifikan 0,05 dan derajat kebebasan $\mathrm{N}-\mathrm{k}=$ $9-1=8$ yakni 2,306 . Karena nilai $\mathrm{t}$ hitung $<\mathrm{t}$ tabel $(0,560<2,306)$ dengan nilai signifikan $>0,05(0,591>0,05)$, sehingga dapat disimpulkan bahwa $\mathrm{H}_{1}$ ditolak atau dengan kata lain tidak terdapat peningkatan NIEFF sesudah meraih peringkat lebih dari taat.

Tabel 12. Hasil Uji Hipotesis

\begin{tabular}{lllll}
\hline & Sebelum & & & \\
& Minimum & Maximum & Mean & Std. Dev \\
\hline ROS & 0,012 & 0,282 & 0,14911 & 0,88305 \\
ROA & 0.019 & 0,421 & 0,14011 & 0,124954 \\
ROE & 0,032 & 1,258 & 0,26144 & 0,383139 \\
SALEFF & 601,128 & 4513974,671 & 934397,81090 & 1855651,832000 \\
NIEFF & 27,410 & 847199,133 & 111371,87210 & 280364,422100 \\
& Sesudah & & & \\
& Minimum & Minimum & Minimum & Minimum \\
ROS & $-0,016$ & $-0,016$ & $-0,016$ & $-0,016$ \\
ROA & 0,10 & 0,10 & 0,10 & 0,10 \\
ROE & 0,008 & 0,008 & 0,008 & 0,008 \\
SALEFF & 130,650 & 130,650 & 130,650 & 130,650 \\
NIEFF & $-59782,450$ & $-59782,450$ & $-59782,450$ & $-59782,450$ \\
\hline
\end{tabular}

Sumber: Data Penelitian, 2018

Proper merupakan instrumen kebijakan alternatif dari Kementerian Lingkungan Hidup untuk mendorong penaatan dan kepedulian perusahaan dalam pengelolaan lingkungan hidup melalui penyebaran informasi tingkat 
kinerja penaatan perusahaan kepada publik dan stakeholder (public information disclosure). Perusahaan Proper yang mendapat predikat dengan "peringkat hijau dan emas" diberikan kepada perusahaan yang telah melakukan pengelolaan lingkungan lebih dari yang dipersyaratkan dalam peraturan (beyond compliance) melalui pelaksanaan sistem pengelolaan lingkungan, seperti pemanfaatan sumberdaya secara efisien melalui upaya 4R (Reduce, Reuse, Recycle dan Recovery), dan telah melakukan upaya tanggungjawab sosial atau Corporate Social Responsibility dengan baik, termasuk kegiatan Community Development. Hasil penilaian peringkat Proper ini dipublikasikan secara terbuka kepada publik dan stakeholder lainnya.

Dengan perolehan peringkat ini tentu citra perusahaan menjadi meningkat dan hal ini berdampak positif pada peningkatan pendapatan atau penjualan. Sistem manajemen lingkungan mengharuskan perusahaan untuk melakukan perbaikan secara terus menerus, sehingga timbul inovasi-inovasi untuk membuat proses produksi barang dan jasa menjadi lebih efisien. Untuk meningkatkan efisiensi operasional, perusahaan melaksanakan upaya perbaikan sistem kerja, perbaikan sarana dan prasaran, serta perbaikan maupun pergantian peralatan produksinya.

Sebagaimana hasil pengujian secara statistika membuktikan bahwa kinerja keuangan dari aspek profitabilitas menunjukkan hasil yang tidak signifikan dilihat dari ROS, ROE, dan ROA ini berarti tidak terjadi perbedaan di lihat dari laba sebelum dan sesudah perusahaan memperoleh peringkat Proper Hijau maupun Emas. Temuan ini dapat mengindikasikan bahwa bagi perusahaan peraih proper, dalam usaha meningkatkan kinerja keuangan terhadap profitabilitas, nampaknya upaya-upaya tersebut tidak berdampak langsung pada kontribusi peningkatan laba terhadap kinerja keuangan.

Efisiensi operasional menunjukkan kemampuan pekerja untuk memberikan kontribusi kepada perusahaan, diukur dari sales efficiency (SALEFF) yang menggambarkan kontribusi per pekerja terhadap penjualan dan net income efficiency (NIEFF) yaitu kontribusi perpekerja tehadap laba. Semakin tinggi SALEFF dan NIEFF berarti operasional perusahaan semakin efisien.

Pengujian Efisiensi operasional dilihat dari Net Income Efficiency (NIEFF), menunjukkan hasil pengujian tidak signifikan. Temuan ini hasil ini membuktikan bahwa tidak ada perbedaan efisiensi operasional dilihat kontribusi per pekerja terhadap laba perusahaan. Pengelolan perusahaan sehingga perusahaan Proper hijau, mampu meningkatkan efiensi operasionalnya melalui kontribusi para karyawan terhadap laba perusahaan sebelum dan sesudah perusahaa memperoleh peringkat Proper hijau.

Hasil pengujian Sales Efficiency (SALEFF) menunjukkan hasil tidak signifikan. hasil ini membuktikan bahwa tidak ada perbedaan efisiensi operasional dilihat kontribusi per pekerja terhadap penjualan sebelum dan sesudah perusahaa memperoleh peringkat Proper hijau. Temuan ini dapat mengindikasikan bahwa bagi perusahaan peraih Proper hijau, dalam usaha meningkatkan efisiensi operasional, perusahaan berupaya memperbaiki sistem kerja, perbaikan sarana dan prasarana, serta perbaikan maupun pergantian perlatan produksi. Nampaknya upaya-upaya tersebut tidak berdampak 
langsung pada kontribusi pekerja terhadap hasil penjualannya (SALEFF), dan NIEFF.

Hasil penelitian memberikan tambahan informasi mengenai bagaimana pengaruh predikat PROPER terhadap kinerja keuangan dan efisiensi oprasional suatu perusahaan yang terdaftar di Bursa Efek Indonesia. Terdapat bukti empiris yang diperoleh dan hasil yang berbeda dengan teori yang dipakai melalui penelitian ini terkait hasil penelitian data yang dilakukan di perusahaan yang tercatat dalam perusahaan yang meraih predikat PROPER dengan periode 20142016 yang menunjukan bahwa kinerja keuangan dan efisiensi oprasional sebelum dan sesudah meraih predikat PROPER tidak berpengaruh terhadap perusahaan.

Hasil penelitian ini dapat menjadi bahan pertimpangan bagi calon investor dalam mengambil keptusan investasi dengan melihat predikat PROPER sebagai salah satu syarat dalam berinvestasi. Pihak investor hendaknya memperhatikan pula faktor-faktor lain dalam berinvestasi karena dilihat dari hasil yang tidak signifikan terhadap perusahaan yang meraih predikat PROPER, yang dewasa ini pengaruh lingkungan berperan sangan penting dalam kelangsungan hidup manusia.

\section{SIMPULAN}

Berdasarkan hasil penelitian ini dapat disimpulkan hal-hal berikut. Perusahaanperusahaan yang meraih peringkat Proper hijau, yang memiliki komitmen tinggi dengan taat dan peduli terhadap pengelolaan lingkungan hidup terbukti bahwa tidak ada peningkatan kinerja keuangan melalui profitabilitas yang di ukur melalui ROS, ROA dan ROE. Hal ini mengindikasikan bahwa bagi perusahaanperusahaan peraih Proper hijau memerlukan usaha yang lebih dalam meningkatkan kinerja keuangan agar investor tertarik menginvestasikan modalnya ke perusahaan peraih predikat PROPER. Perusahaan Proper hijau menunjukkan hasil tidak signifikan terhadap efiensi operasionalnya melalui Net Income Efficiency (NIEFF) yaitu kontribusi per karyawan terhadap laba perusahaan dan Sales Efficiency (SALEFF) menunjukkan hasil tidak signifikan. Hal ini mengindikasikan bahwa bagi perusahaan peraih Proper hijau, dalam usaha meningkatkan efisiensi operasional, perusahaan berupaya memperbaiki sistem kerja, perbaikan sarana dan prasarana, serta perbaikan maupun pergantian pearlatan produksi. Upaya-upaya tersebut tidak berdampak langsung pada kontribusi pekerja terhadap hasil penjualan (SALEFF).

Bagi perusahaan-perusahaan PROPER utamanya yang memperoleh predikat lebih dari taat dalam pengelolaan lingkungan (Proper hijau), ke depan hendaknya lebih memperhatikan kinerja keuangan dari aspek leverage (DER) dan pembayaran dividen kepada para pemegang saham (dividend payment DIVSAL). Bila hal ini kurang mendapat perhatian, akan dapat berdampak tidak baik pada citra perusahaan secara keseluruhan.

Penelitian mendatang dapat mengkaji kembali model penelitian ini dengan memperhatikan periode waktu setelah peringkat Proper diraih, yang mana dalam penelitian ini hanya melihat kondisi satu tahun setelah peringkat tersebut diperoleh dan lebih memperhatikan reaksi pasar terhadap perusahaan yang memperoleh predikat lebih dari taat pada perusahan yang terdaftar di BEI. 
Sebagaimana hasil penelitian ini menunjukkan hasil yang tidak signifikan untuk kinerja keuangan pada aspek ROA, ROE, ROS, SALEFF, NIEFF. Hal ini dapat terjadi karena perhatian perusahaan terhadap pengelolaan lingkungan dapat berdampak jangka panjang bagi keberhasilan bisnisnya.

\section{REFERENSI}

Al-Tuwaijri, S.A.,Christensen, T.E. dan Hughes, K.E. (2004). The Relations among environmental disclosure, environmental performance, and economic performance: a simultaneous equations approach.Accounting,Organizations and Society Journal. 29(2) , pp.447-471.

Chariri, A. dan I. Ghozali. (2007). Teori Akuntansi. Semarang: Badan Penerbit Universitas Diponegoro.

Bank Indonesia. (2005). Peraturan nomor 7/2/PBI/2005 tentang penetapan peringkat kualitas aktiva bagi bank umum.

Benny, D. S dan Azhar, K. (2007). Pengaruh Kinerja Lingkungan dan Pengungkapan Informasi Lingkungan Terhadap Kinerja Ekonomi Perusahaan Manufaktur Yang Terdaftar di Bursa Efek Indonesia. Jurnal Akuntansi Fakultas Ekonomi dan Bisnis Universitas Sumetera Utara, Medan, hal.569-580.

Djogo, Tony. (2006). Akuntansi Lingkungan (Environmental Accounting). Erlangga: Jakarta.

Halim, Abdul dan Mamduh M. Hanafi. (2009). Analisis Laporan Keuangan. Edisi4. UPP STIM YKPN. Yogyakarta.

Hanafi. (1995). Manajemen Keuangan . Edisi 1. Yogyakarta : BPFE Yogyakarta.

Luciana Spica Almilia dan Dwi Wijayanto. (2007). Pengaruh variabel EnvironmentalPerformance, Unexpected Earning, Pre-Disclosure Environment, Growth Opportunities, dan Profit Margin terhadap Economic Performance.Jurnal AkuntansiUniversitas Diponogoro, Semarang, hal. 576-580.

Lestari, M.I., dan Sugiharto, T. (2007). Kinerja Bank Devisa dan Bank NonDevisa dan Faktor-faktor yang Mempengaruhinya. Jurnal AkuntansiUniveritas Tarumanegara, 2 (4). hal. 345-350.

Munawir. (2001). Analisa Laporan Keuangan, Yogyakarta : Liberty

Nugraha. (2007). Pengaruh Kinerja Lingkungan Perusahaan Terhadap Kinerja Keuangan Perusahaan di Indonesia. Jurnal AkuntansiFakultas Ekonomi dan Bisnis Universitas Gajahmada, hal.450-465.

Nuraini, Eiffeliana. (2010). Pengaruh Environmental Performance dan Environmental Disclousure Tehadap Economic Performance ( Studi Perusahaan yang Terdaftar di Bursa Efek Indonesia). Jurnal AkuntansiUniversitas Diponogoro, hal.657-670.

Peraturan Pemerintah No. 27 Tahun 1999 tentang Analisis Mengenai Dampak Lingkungan Hidup.

Permatasiwi, D. A. (2010). Hubungan Kinerja Sosial dan Kinerja KeuanganPerusahaan. Jurnal Akuntansi. Universitas Diponegoro, hal.467479.

Rakhiemah, Aldilla Noor dan Dian Agustia. (2009). Pengaruh Kinerja Lingkunganterhadap Corporate SocialResponsibility (CSR) Disclosure 
danKinerja Financialperusahaanmanufaktur yang terdaftar di BursaEfek Indonesia. Jurnal AkuntansiFakultas Ekonomi dan Bisnis Universitas Airlangga, hal.658-667.

Rawi. (2010). Kepemilikan Manajerial, Kepemilikan Institusi, Leverage, dan Corporate Social Responsibility. Jurnal Universitas Purwokerto Fakultas Ekonomi dan Bisnis, hal. 550-560.

Sarumpaet, Susi. (2005). The Relationship Between Enviromental Performance andFinancial Performance of Indonesian Companies. Jurnal Akuntansi dan Keuangan Universitas Airlangga , 7(2), hal.245-260.

Setyaningsih dan Asyik. (2016). Pengaruh Kinerja Lingkungan Terhadap Kinerja Keuangan dengan Corposate Social Responsibility Sebagai Pemoderasi. Jurnal Ilmudan Riset Akuntansi, 5(4), hal.456-462.

Sawir, Agus. (2001). Analisis Kinerja Keuangan dan Perencanaan Keuangan Perusahaan. Jakarta: Gramedia Pustaka Utama.

Suratno, Ign Bondan. Darsono. dan Siti Mutmainah. (2006). Pengaruh Environmental Performance terhadap Environmental Disclosure dan Economic Performance (Studi Empiris pada Perusahaan Manufaktur yang Terdaftar di Bursa Efek Jakarta Periode 2001-2004. Jurnal AkuntansiUniversitas Padang, hal 459-465.

Simamora, Henry. (2004). Manajemen Sumber Daya Manusia. Edisi Ketiga. Cetakan Pertama. Yogyakarta: STIE YKPN.

Sudaryanto. (2011). Pengaruh kinerja lingkungan terhadap finansial perusahaan dengan corporate social responsibility (CSR) disclosure sebagai variabel intervening. Jurnal AkuntansiUniversitas Diponegoro, Semarang, hal.468475.

Undang-Undang Republik Indonesia No. 40 Tahun 2007 Tentang Perseroan Terbatas.

Undang-Undang Republik Indonesia Hidup Nomor 23 Tentang Lingkungan Hidup. 